\title{
Summary of Results Obtained during a Preliminary Investigation into the Bacterial and Botanical Flora of Caves in South Wales
}

\author{
By M. Ann Mason Williams ${ }^{1}$ ) and Kathryn Benson-Evans ${ }^{2}$ )
}

In 1958 a paper, "A preliminary investigation into the bacterial and botanical flora of caves in South Wales" was published by the Cave Research Group of Great Britain. In it the authors, Ann Mason Williams and Kathryn Benson-Evans, gave details of an investigation into the populations of algae and bacteria found in caves in South Wales.

In view of the interest shown in the original paper, the editors kindly offered one of the authors the opportunity to re-publish the results. These are given in the form of tables with relevent comments appended.

The work reported in the original paper raised several important questions concerning the ecology of caves.

1. The effects of air-currents on the distribution of the microflora of caves.

2. The importance and significance to the cave environment of floods and visiting animals, including man.

3. The role of bacteria in the food chains of aquatic animals in caves.

4. The probable importance of the autotrophic micro-organisms in the economy of cave life.

Since the publication of the original paper, work has been carried out on these and other problems associated with the microbial populations of caves and the results are reported in papers in preparation.

\footnotetext{
1) Department of Microbiology, University College, Cardiff, U. K.

2) Department of Botany, University College, Cardiff U. K.
} 
Table 1

Average numbers of bacterial colonies developing on nutrient agar plates following exposure of the plates to the air for 30 minutes within various caves. The counts are those which had developed after 7 days incuation

\begin{tabular}{|c|c|c|c|c|}
\hline \multicolumn{2}{|c|}{ Incubation temperature } & \multirow{2}{*}{$\frac{37^{\circ} \mathrm{C} .}{30}$} & \multirow{2}{*}{$\frac{30^{\circ} \mathrm{C} .}{20}$} & \multirow{2}{*}{$\frac{18^{\circ} \mathrm{C} .}{70}$} \\
\hline Porth yr Ogof: & site 1. & & & \\
\hline & site 2. & 0 & 20 & 25 \\
\hline & site 3. & 2 & 0 & 18 \\
\hline \multirow[t]{3}{*}{ Little Garth: } & site 1. & 16 & 150 & 200 \\
\hline & site 2 . & 0 & 70 & 25 \\
\hline & site 3. & 0 & uncountable ${ }^{2}$ ) & 3 \\
\hline Bridge $\operatorname{Cave}^{1}$ ) & site 1. & 16 & 15 & 16 \\
\hline Ogof Ffynnon Ddu. & site 1. & 100 & 220 & 250 \\
\hline Cave B & site 1. & 20 & 11 & 100 \\
\hline Cave $\mathrm{C}$ & site 1. & 20 & 50 & 25 \\
\hline
\end{tabular}

Table 2

Species of bacteria isolated from the air of various caves in South Wales (In the original paper, the species are given under the headings of the various caves from which they were isolated)

\begin{tabular}{ccc}
\hline & Incubation temperature \\
$37^{\circ} \mathrm{C}$. & $30^{\circ} \mathrm{C}$. & $18^{\circ} \mathrm{C}$. \\
\hline
\end{tabular}

\begin{tabular}{lll}
\hline Bacillus subtilis & Bac. cereus & Bac. cereus v. mycoides \\
Bac. megaterium & Bac. cereus v. mycoides & Bac. megaterium \\
Bac. pumilus & Bac. subtilis & Bac. spp. \\
Bac. spp. & Bac. megaterium & Bact. qualis \\
Bacterium qualis & Bac. spp. & Bact. mutabile \\
Bact. mutabile & Bact. qualis & Bact. spp. \\
Bact. spp. & M. luteus & Achromobacter sp. \\
Achromobacter $\mathrm{sp}$. & M. freudenreichii & M. freudenreichii \\
Flavobacterium $\mathrm{sp}$. & M. spp. (orange, buff & M. flasus \\
Micrococcus sp. & and white) & M. spp. (orange and \\
(orange pigmented) & Sarcina lutea & white pigmented) \\
M. luteus & Corynebacterium helvolum & Nocardia flasa \\
Micrococcus spp. & Nocardia sp. & Microbacterium sp. \\
(cream to white) & Streptococcus salivarius & \\
Sarcina sp. & & \\
Streptomyces albus & & \\
Nocardia rubra & & \\
Nocardia sp. & & \\
\end{tabular}

1) The plates from this site were all uncountable due to overgrowth of other species by a few rapidly growing species of Bacillus.

$\left.{ }^{2}\right)$ All the plates from this site showed numerous colonies of moulds many of which showed zones of inhibition around them. 
In the original paper it was remarked that the species and total numbers of bacteria found in the air of caves could be related to various known disturbances within and near the caves. For example, two sites gave noticeably high counts, site 1, the entrance passage in the Little Garth Cave, and site 1 in Ogof Ffynnon Ddu. These counts were attributable to frequent disturbance of the air and soil at these sites due to quarrying near the entrance to the Little Garth Cave, and to visiting cavers in Ogof Ffynnon Ddu. during the sampling times. Work done since the publication of the original paper has confirmed the view that the air flora of many of the smaller British caves is related directly to the frequency of disturbance of the cave air by outside influences. The air currents within the caves distribute the species brought in from outside the cave on clothing, by floods, or in animal droppings.

\section{Table 3}

Species of bacteria isolated from soil and water samples taken within the various caves

\begin{tabular}{ll}
\hline \multicolumn{1}{c}{ Soil } & \multicolumn{1}{c}{ Water } \\
\hline Bacillis subtilis & Bacillus cereus \\
Bac. cereus v. mycoides & Bac. cereus v. mycoides \\
Bac. cereus & Bac. sp. \\
Bac. sp. & "Clostridium pasteurianum \\
Bact. sp. & Bacterium sp. \\
Pseudomonas fluorescens & Escherichia coli (irregular) \\
Ps. pyocyanea & Aerobacter aerogenes \\
Achromobacter sp. & Micrococcus nitrificans \\
Citrobacter sp. & M. spp. \\
Micrococcus sp. & Leuconostoc sp. \\
Leuconostoc sp. & Streptomyces albus \\
" Clostridium pasteurianum ${ }^{1}$ ) & Nocardia sp. \\
Nocardia sp. & Microbacterium sp. \\
" Azotobacter sp. & "Azotobacter aquatile \\
"Nitrobacter winogradskyi & "Nitrobacter winogradskyi \\
"Nitrosococcus europaea & "Nitrosomonas europaea \\
& "Nitrosococcus sp. \\
& "Thiobacillus novellus
\end{tabular}

It will be noticed that the list given here includes a number of species capable of utilizing inorganic nitrogen for their nitrogen re-

\footnotetext{
1) Since the publication of the original paper, investigations into the species of anaerobic bacteria present in the muds of caves have shown that a wide variety of clostridial species are present in most caves. The commonest species are $C l$. tetani, Cl. butyricum and Cl. histolyticum.
} 
quirements, thus converting it to an organic form of use to other forms of life. These species are marked ".

In the original paper it was pointed out that the list gives only those species which could be identified to generic or specific level. The problem of the identification of the relatively large numbers of small gram indeterminate rods which have been found in the soil and water of caves is one which is also encountered by soil microbiologists and which still remains to be solved.

\section{Botanical Results}

It is not practical to give complete lists of the plants found, and only the more important features of them are given in this summary.

The botanical work was divided into two main parts, those plants associated with the threshold and those found within the cave.

Table 4

Macroscopic plants found in the threshold areas of caves

ANGIOSPERMS :

Chrysosplenium oppositifolium Outer regions with fairly high light intensity Oxalis acetosella PTERID OPHYTA:

Asplenium trichomanes

Asp. rutamuraria

Phyllitis scolopendrium

Athyrium filix-femina

Shady damp thresholds

Alka-tolerant forms growing on substrates of $\mathrm{pH} 6.0-7.0$

Only on more acid substrates, pH 5.5

BRYOPHYTES: 1. MUSCI :

Amblystegium serpens

Barbula recurvirostre

Mesophilous forms tolerating $\mathrm{pH}$ values

Thamnium alopecurum of $4.8-7.0$ found at most of the caves visited

Fissidens bryoides

F. taxifolius

Ctenidium molluscum

Mnium punctatum

Mnium undulatum

M. longirostrum

Mesophilous forms but found less frequently

Eurhynchium murale

Campylium sommerfeltii

Polytrichum juniperinum

Isopterygium elegans

Hypnum cupressiforme

Blindia acuta

Sphagnum plumulosum

Acid tolerant forms found at a few sites only 
Tabelle 4 (Fortsetzung)

Macroscopic plants found in the threshold areas of caves

BRYOPHYTES: 2. HEPATICAE:

Pellia epiphylla

Plagiochila asplenoides

Pellia fabbroniana

Mesophilous forms found at most of the sites visited

Conocephalum conicum

Mesophilous but found less frequently

In the threshold regions, the two important ecological factors were the substrate and the penetration of light. The light factor is of great importance, bringing about a distinct zonation of plants according to the light intensity they receive. A subsidiary effect of the light factor is that of its aspect. Marked differences in amounts of growth can be seen by comparing north-facing walls, which show abundant growth, with south-facing walls, which show scanty, and often atypical growth.

Amongst the bryophytes, the effect of the reduced light intensities was most noticeable in the changes which occurred in the growth habits of the various species found. At the higher light intensities, more or less normal growth forms were observed, but as the light intensity decreased, dendroid forms and smooth mats became less frequent, and growth occurred in rough or thalloid mats and wefts.

In the threshold areas, the species of algae found on the rocks and soil were limited, and the species found were mainly coccoid forms from the Myxophyta and the Chlorophyta, together with a few Diatoms, and one or two filamentous members of the Chlorophyta.

Within the Dark Zones of the caves, the only macroscopic green plants found growing were etiolated seedlings of oak, sycamore and the rush Juncus buffonius.

Cultural methods demonstrated that there are spores of many plants present in the soil of caves. Spores of bryophytes found around the threshold areas were very common, and seemed widespread through the caves from which soil samples were taken. The potential algal flora of caves is also very considerable, and cultural methods showed that light was the only limiting factor in preventing growth. The amount of growth obtained in experiments in which soil samples were illuminated for only 30 minutes, and then incubated in the dark, proved that algal spores are present in considerable quantities. It is postulated that the spores are present in sufficient quantities to provide sources of organic matter for saprophytic troglophiles. 


\section{SUMMARY}

The results of an investigation into the bacterial and botanical flora of South Welsh caves are presented in tabular form. Bacterial counts and species isolated from the caves both from soil and water samples as well as from the air, also the macroscopic plants found in the photic zone are enumerated.

\section{ZUSAMMENFASSUNG}

Die Ergebnisse der bakteriologischen und botanischen Untersuchung der Flora in den Süd-Wales-Höhlen sind tabellarisch dargestellt. Verzeichnet sind bakteriologische Zählungen, von Erd-, Wasser- sowie Luftproben isolierte Arten und auch die makroskopischen Pflanzen der belichteten Zone.

\section{REFERENGE}

Mason-Williams, M. A., and Benson-Evans, K. (1958) - A preliminary investigation into the bacterial and botanical flora of caves in South Wales. Cave Research Group of Great Britain. Pub. No. 8. 